\title{
Food intake of university students
}

\section{Consumo alimentar de estudantes universitários}

\section{A B S T R A C T}

This narrative literature review aimed to analyze the results of studies on the food intake of university students. A literature search was conducted in July 2014 and updated in July 2016 in the Scopus, MedLine/PubMed, and SCIELO databases, using descriptors related to university students and food intake in English and Portuguese. Overall, 37 studies that analyzed university students' food intake were included in this review, eight of which were conducted in Brazil. The results demonstrated that most university students have unhealthy eating behaviors, such as high intake of fast foods, snacks, sweets, soft drinks, and alcoholic beverages, and low intake of fruits, vegetables, fish, whole grains, and legumes. Undergraduate students of health sciences, such as nursing, nutrition, and medicine, did not have healthier diets. University students' food intake was characterized as unhealthy, regardless of undergraduate program or sex, especially among students who left the parents' home and became responsible for their own food. Therefore, there is a need of developing public policies that promote healthy eating habits among students, such as interventions to change their eating habits and increase their access to healthy foods at the university environment.

Keywords: Eating. Healthy diet. Public policies. Students. Universities.

\section{R E S U M O}

O estudo teve o objetivo de realizar revisão narrativa de literatura para analisar os resultados de estudos sobre o consumo alimentar de estudantes universitários. Realizou-se busca bibliográfica, em julho de 2014, atualizada em julho de 2016, nas bases de dados Scopus, MedLine/PubMed e SciELO, utilizando unitermos relacionados a estudantes universitários e a consumo alimentar, em língua inglesa e portuguesa. No total, 37 artigos sobre o consumo alimentar de universitários foram analisados e discutidos nesta revisão. Dentre os estudos incluídos, 8 foram realizados no Brasil. Os resultados dos estudos demonstram que a maioria dos estudantes universitários

\footnotetext{
1 Universidade Federal de Santa Catarina, Departamento de Nutrição, Núcleo de Pesquisas de Nutrição em Produção de Refeições. Campus Universitário, Trindade, 88040-900, Florianópolis, SC, Brasil. Correspondência para/Correspondence to: RPC PROENÇA. E-mail: <rossana.costa@ufsc.br>.
} 
apresenta comportamentos alimentares pouco saudáveis, como o elevado consumo de fast food, snacks, doces, refrigerantes e bebidas alcoólicas, bem como baixo consumo de frutas, legumes, verduras, peixes, cereais integrais e leguminosas. Cursar graduação na área da saúde, como enfermagem, nutrição e medicina não foi indicativo de ter uma alimentação mais saudável. O consumo alimentar de estudantes universitários foi caracterizado como pouco saudável, independentemente de curso de graduação e sexo, destacando-se aqueles estudantes que saíram da casa dos pais e passaram a ser responsáveis pela própria alimentação. Sugere-se a elaboração de políticas públicas que estimulem a promoção da alimentação saudável dos estudantes, a exemplo de intervenções para mudanças nas práticas alimentares e para aumento do acesso a alimentos saudáveis no ambiente universitário.

Palavras-chave: Ingestão de alimentos. Dieta saudável. Políticas públicas. Estudantes. Universidades.

\section{N TROD UCTIO N}

University education may be considered a transition period between adolescence and adulthood, one in which students become independent from their parents and acquire new health behaviors [1].

Given the time adolescents and young adults spend at universities and nearby areas, said sites may influence the eating habits of these students in adulthood [2]. Moreover, international studies show that attending university may increase the prevalence of overweight and obesity, weight gain, and unhealthy lifestyles, which have been associated with a higher risk of chronic diseases [1,3].

University life and its dietary context are often associated with inappropriate eating habits in students. At foreign studies, university students' food intake is characterized by a higher intake of snacks, fast foods, French fries, cakes, pies, and carbonated beverages, and a lower intake of fruits and vegetables [4-6]. Hence, the time spent at university is recognized as an important phase to promote students' health and prevent diseases [1].

Some studies have discussed the possible barriers to and facilitators of healthier eating habits among young adults [7-10].

Current food intake studies are concerned with healthful eating in this group. Nonetheless, reviews that discuss the results of studies on university students' food intake and establish a common profile for those students have not been found. According to Alves \& Boog [11], understanding the eating behavior of these young adults is important because it allows the development of health-promoting interventions.

In this context, the objective of this article was to make a narrative literature review to analyze the results of Brazilian and foreign studies that investigate university students' food intake. This review attempted to answer the following question: How does characterize the food intake of university students?

\section{METHODS}

This narrative literature review included information from exploratory studies, available in the scientific literature, on the food intake of university students.

A literature search was conducted in July 2014 and updated in July 2016 in the following databases: Scopus, MedLine/PubMed, and Scientific Electronic Library Online (SciELO). An additional search using the snowball method was performed, selecting the references in the review studies obtained from the initial search.

The terms used for the literature search were defined by the Medical Subject Headings of United States National Library of Medicine, and the Health Sciences Descriptors (SHDe) and the keywords of studies found in the previous search. The search was conducted by combining the descriptors in English and Portuguese as follows: "feeding practic\$," "food practic\$", "eat\$ habit\$", "eat\$ practic\$", "eat\$ behavior", 
"diet\$ habits", "food habits", "food behavior", "food consumption", "food intake", "health\$ behavior", "nutritio\$ habits", "university students", "college students", "undergraduate students", "freshman", "sophomore", "young adults". Date-related restrictions or other search filters were not used. The combinations were adapted to use more general or more specific terms based on the limitations of each database.

This review investigated exploratory studies that analyzed the food intake of university students and papers with repeated data from similar sources were excluded, prioritizing inclusion of the original sources. The studies, which analyzed the intake of food or food groups, or the dietary patterns of university students, were read and judiciously analyzed in full text. Thus, the studies were characterized by author, year of publication, location, type of study, sample, food intake assessment instruments, dietary outcomes, and main results. The common results were grouped and presented separately in Brazilian and foreign studies.

Analysis of the results of studies on the food intake of university students emerged in a discussion about the possible barriers to and facilitators of healthful eating among university students, and the barriers and facilitators were presented in a specific section as a secondary issue of the present review. For this purpose, the main characteristics of healthful eating considered by this review refer to the respect for and appreciation of cultural practices, access to fairly priced foods, and appreciation of variety, flavor, color, safety, proper amount, and proper quality [12].

\section{University students' food intake: Brazilian and foreign studies}

This review included 37 studies, eight of which were conducted in Brazil. Of the foreign studies $(n=29), 58.6 \%$ were conducted in Europe $(41.0 \%$ in Spain), $17.2 \%$ in North America, $13.8 \%$ in the Middle East (all of them in Saudi Arabia), 6.9\% in South America, and $3.5 \%$ in Africa (South Africa).

Chart 1 [13-41] synthesizes the foreign studies that analyzed the food intake of university students.

The most investigated inadequacies found in the results of foreign studies were the high intake of fast foods, snacks, deep-fried foods, and sweets $[15,18,20,33,34,36,39,41]$, carbonated and other sugar-sweetened beverages $[13,17,23,25,29,34,40]$, energy drinks $[17,29,38]$, refined grains and sugars $[18,26,27,30,33]$, and alcoholic beverages, especially beers $[15,28,34]$.

The main outcome investigated by most foreign studies was the frequency of students' fruit and vegetable intake according to international recommendations, and said intake was low in all analyzed studies [13,15,17,18, 20,23,26,27,29,30-36,38,41]. Additionally, some studies have also found a low intake of dietary fibers $[26,30,32,33]$.

Seafood was another food group investigated by foreign studies, and the studies found that seafood was not or little consumed by students $[15,17,26,27,29,33,34,41]$. On the other hand, students had high intakes of milk and dairy products $[18,26,27,30]$, refined grains, and sugars $[18,26,27,30,33]$.

Regarding main meal intake, breakfast was the most skipped main meal by university students at foreign studies [13,29,34,36,38-41], followed by lunch $[18,27,36]$ or dinner/supper $[34,36]$. In addition results of foreign studies reported the university students' habit of snacking throughout the day, between main meals, often consuming low-nutrient-dense foods, such as snacks or sandwiches, sold at university cafeterias $[13,29,40]$.

In contrast, three Spanish studies $[26,27,30]$ and one Canadian study [17] found that most of students investigated had the habit to eat breakfast daily. Even though few foreign studies assessed the impact of breakfast on the 


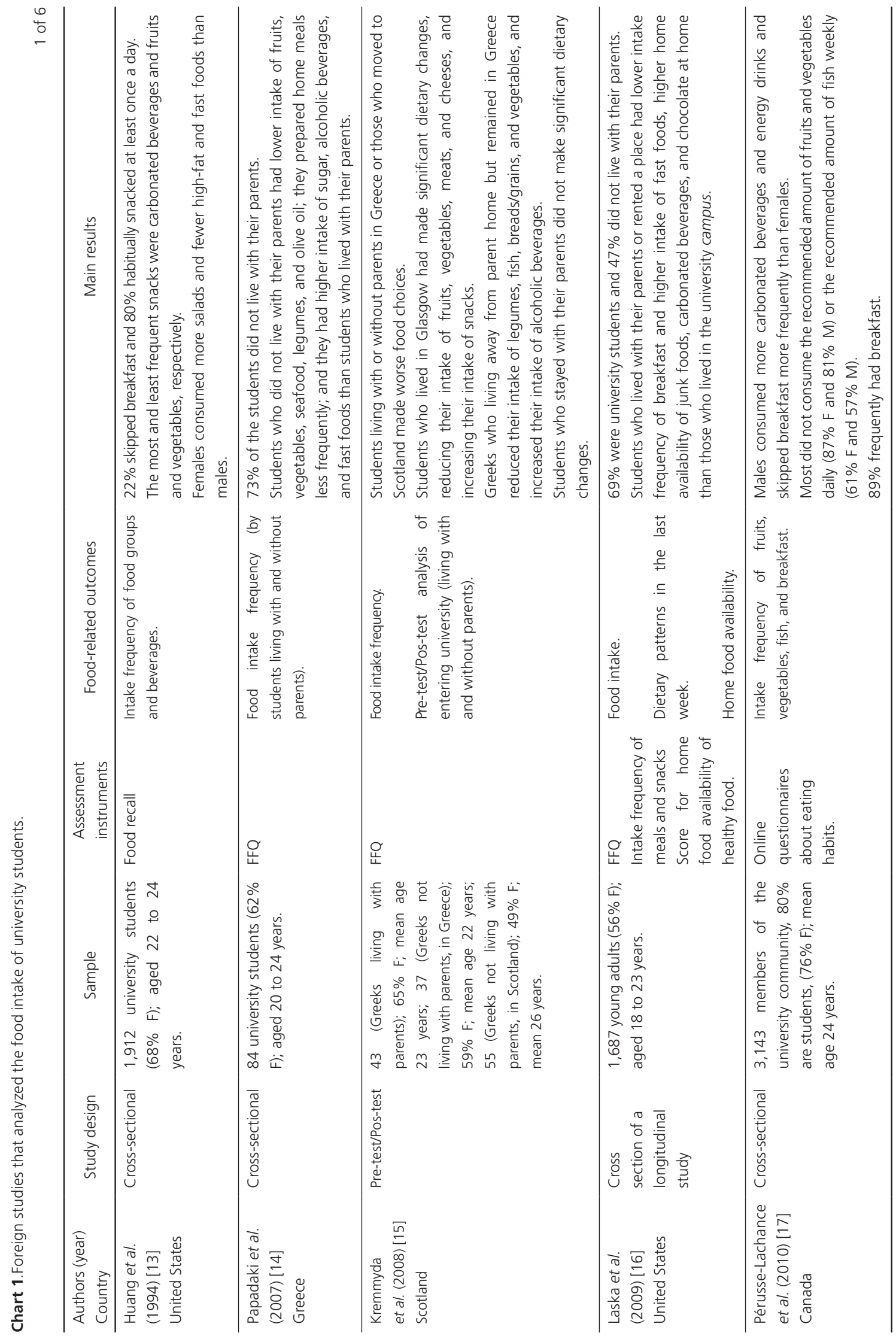




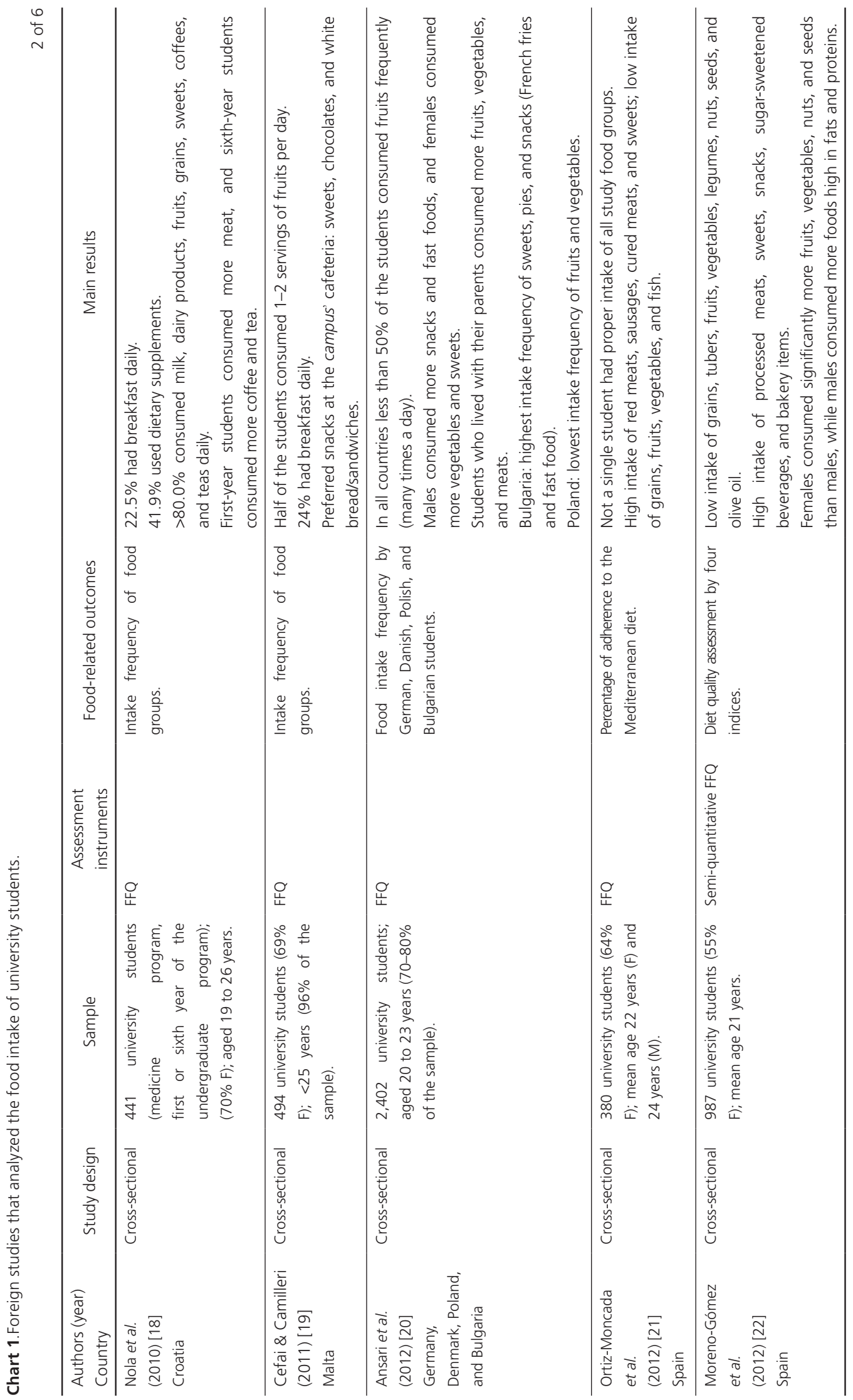




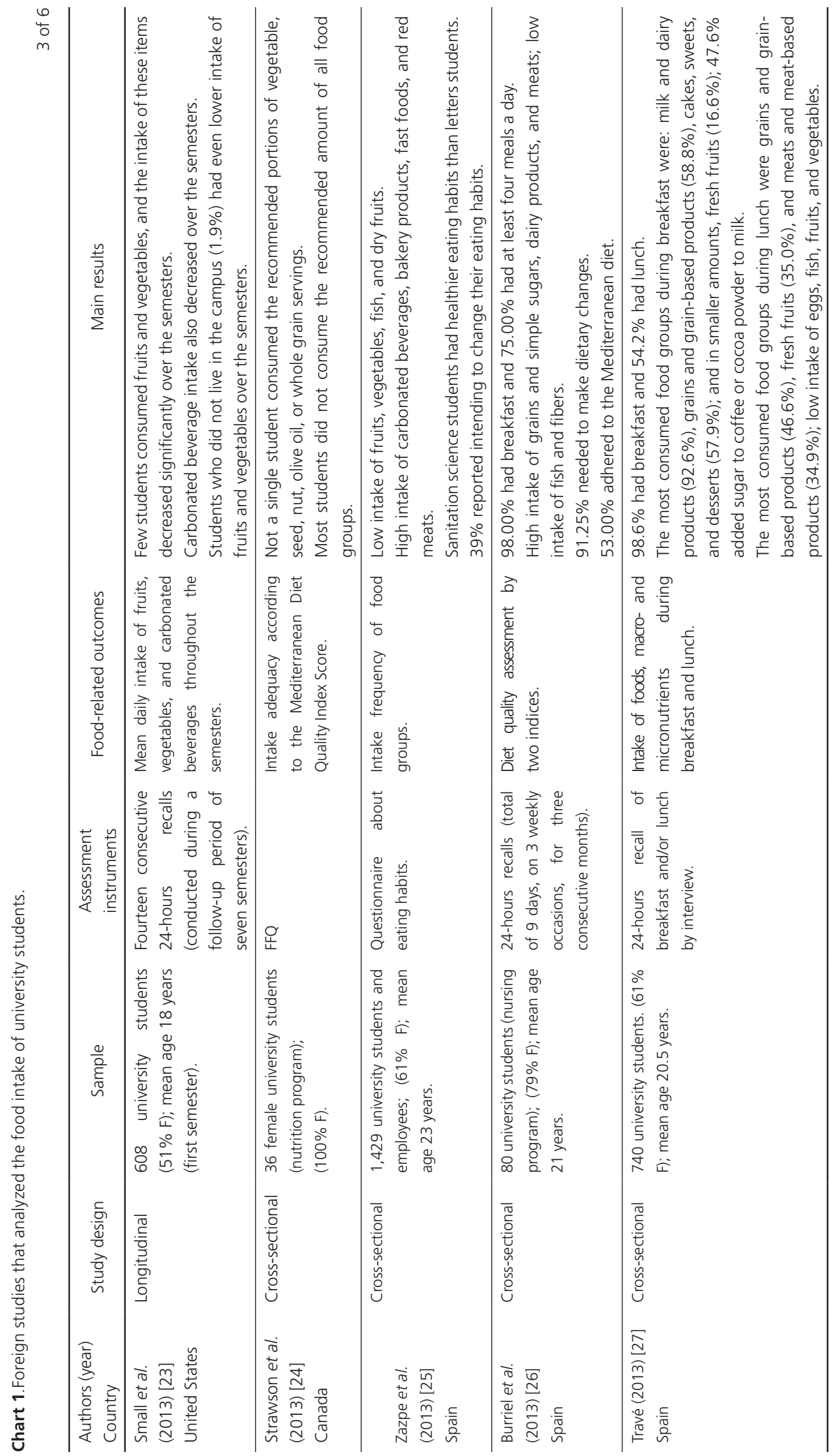




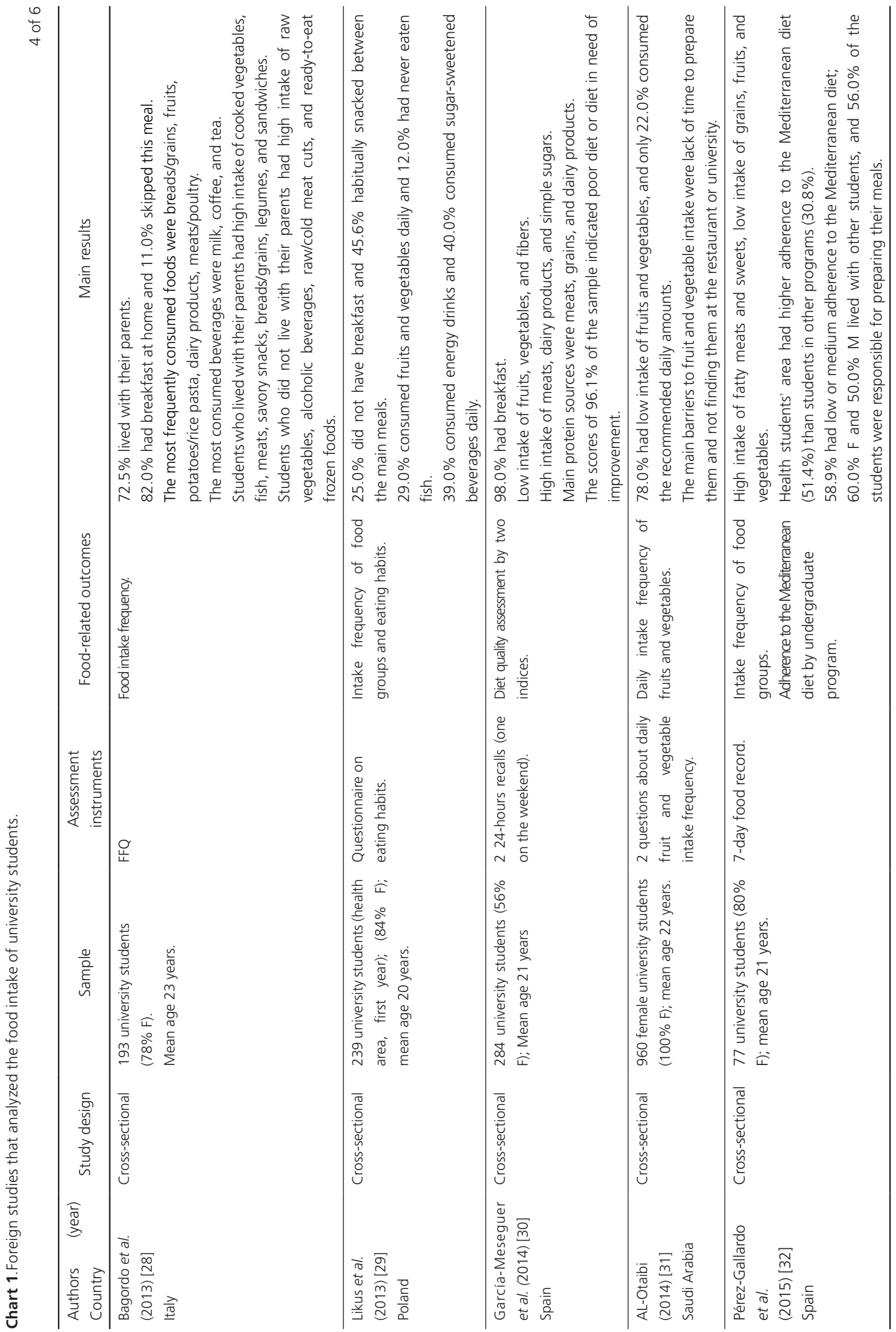




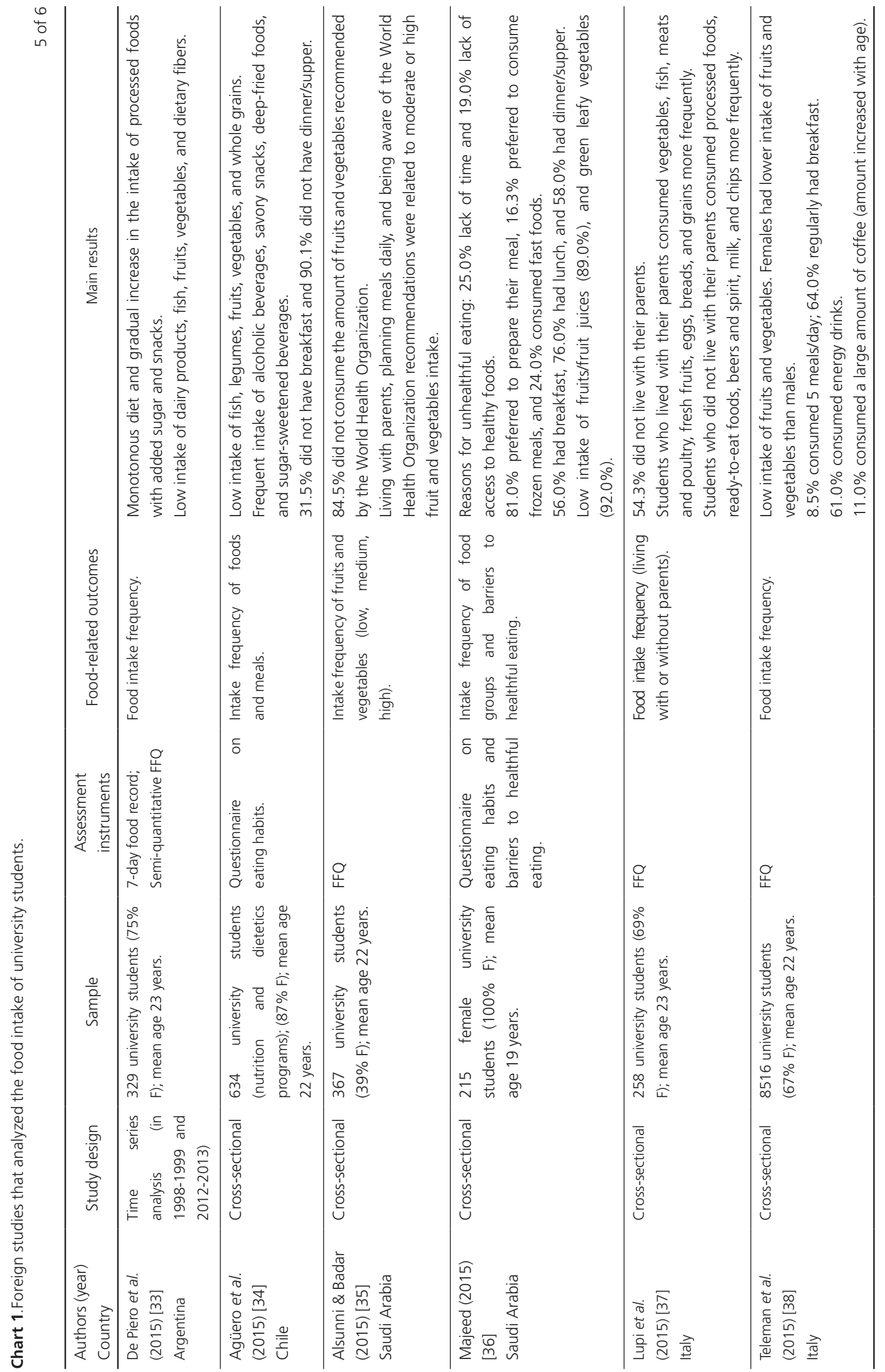




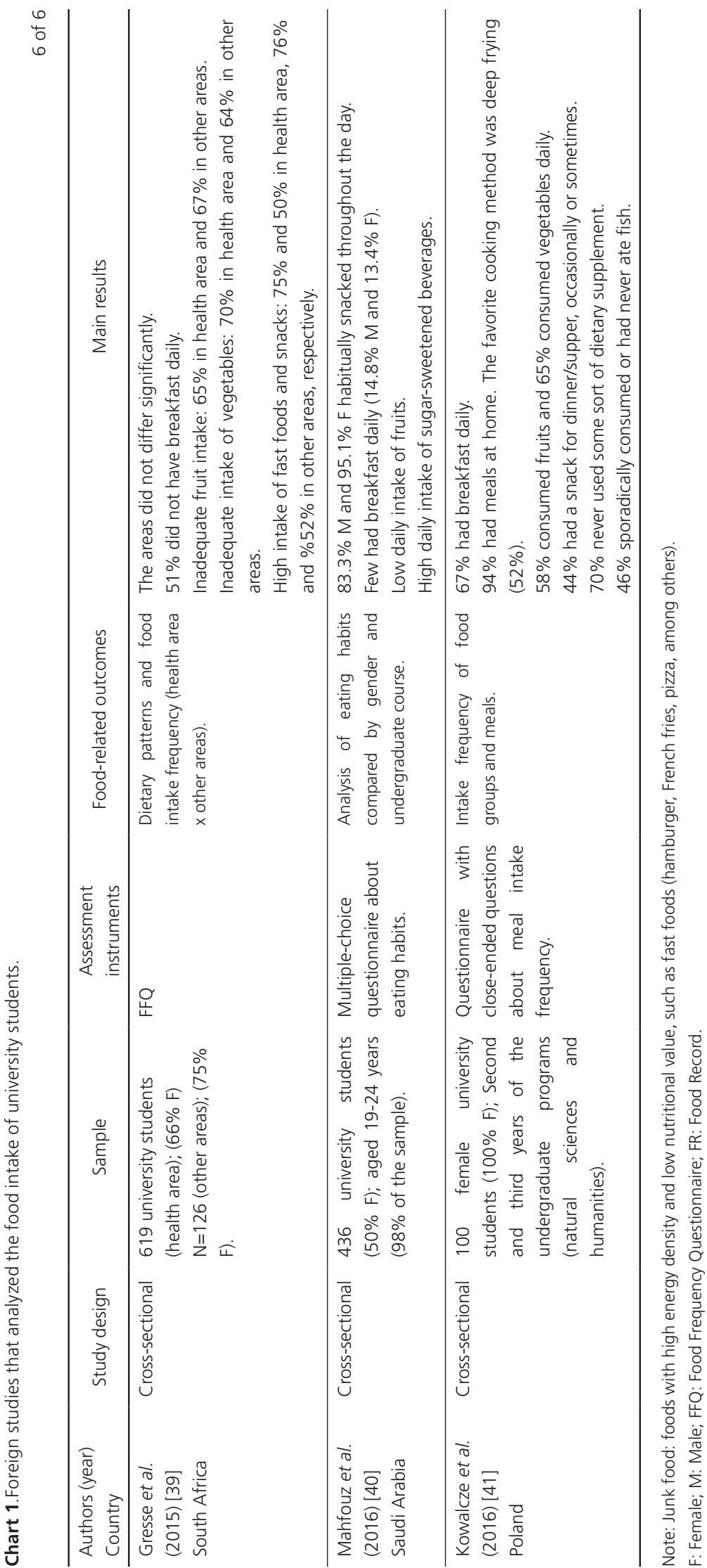


health of adolescents and young adults, there is solid scientific evidence on the benefits of regular breakfast intake for children and adolescents' academic performance, cognitive function [42], and diet quality $[43,44]$.

Spanish studies $[21,22,26,30,32]$ investigated the percentage of university students' adherence to the Mediterranean diet, analyzing the intake frequencies of fruits, vegetables, fish, whole grains, legumes, nuts, seeds, and olive oil. These studies found that most students investigated needed changes on diet to make healthier dietary patterns and pointed out the low adherence to the Mediterranean diet.

Chart 2 [45-52] synthesizes the Brazilian studies that analyzed university students' food intake. Three of the eight Brazilian studies were conducted in the Southeast, three in the Northeast, one in the North, and one in the Federal District.

Brazilian study results were similar to foreign study results. Most studies on the food intake of Brazilian university students found that they had low intakes of fruits and vegetables [45-51], fish [47], and whole grains [46], skipped main meals [45], and had high intakes of fast foods [50], alcoholic beverages [45,46,48,51], carbonated beverages, and sweets $[46,47]$. On the other hand, two studies reported that most students investigated had the habit to consume legumes daily, especially beans $[46,48]$, which may indicate students' preference for the traditional Brazilian diet.

These results corroborate a Brazilian study conducted by Maciel et al. [53], which included 303 individuals of the university community, namely students, professors, and other employees of a public university in São Paulo city. Their results also suggest low intake of fruits, vegetables, and whole grains. In addition their sample had low intake of legumes.

A Brazilian study of 47 female students attending the first year of nutrition and nursing programs found that $48.9 \%$ were or had been on some kind of diet. This may indicate that these young women were concerned with their body image, trying to reach or maintain a beauty standard. Moreover, the need of adhering to a dietary pattern may stem from their being females and most studying nutrition [47].

The approach of identifying dietary intake patterns instead of food or food group intakes is still little explored, even though said approach has been appreciated in the nutritional epidemiology literature. Only three Brazilian and foreign studies on the food intake of university students assessed dietary patterns $[16,39,52]$. Nevertheless, only one Brazilian study, conducted by Pereira-Santos et al. [52], identified and discussed four dietary patterns in students, namely, the traditional pattern, exam day pattern, end-of-semester pattern, and anxiety pattern. Therefore, this literature gap represents an interesting subject for future studies.

The methods used by studies that investigated the food intake of university students varied greatly. Most foreign studies (90\%) were cross-sectional, one was of the pretest/post-test type [15], one was longitudinal [23], and one was a time series analysis [33]. All Brazilian studies had a cross-sectional design.

The instruments used for assessing university students' food intake also varied. Most foreign studies (76\%) used the Food Frequency Questionnaire (FFQ), followed by the 24-hour recall (21\%), 7-day food record (7\%) [32,33], and a score for home food availability of healthy foods (3\%) [16]. Thirty-eight percent of the studies used non-validated instruments, 35\% used validated instruments, and $27 \%$ adapted instruments without validating the adaptations for the target population. Most Brazilian studies (5 of 8 ) also used the FFQ, two used a semiquantitative FFQ $[48,49]$, and one used the instrument Indicador de Saúde e Qualidade de Vida Acadêmicos (University Student Health and Quality of Life Indicators) [51]. Four studies used validated instruments [47,49,51,52], and four used non-validated instruments 


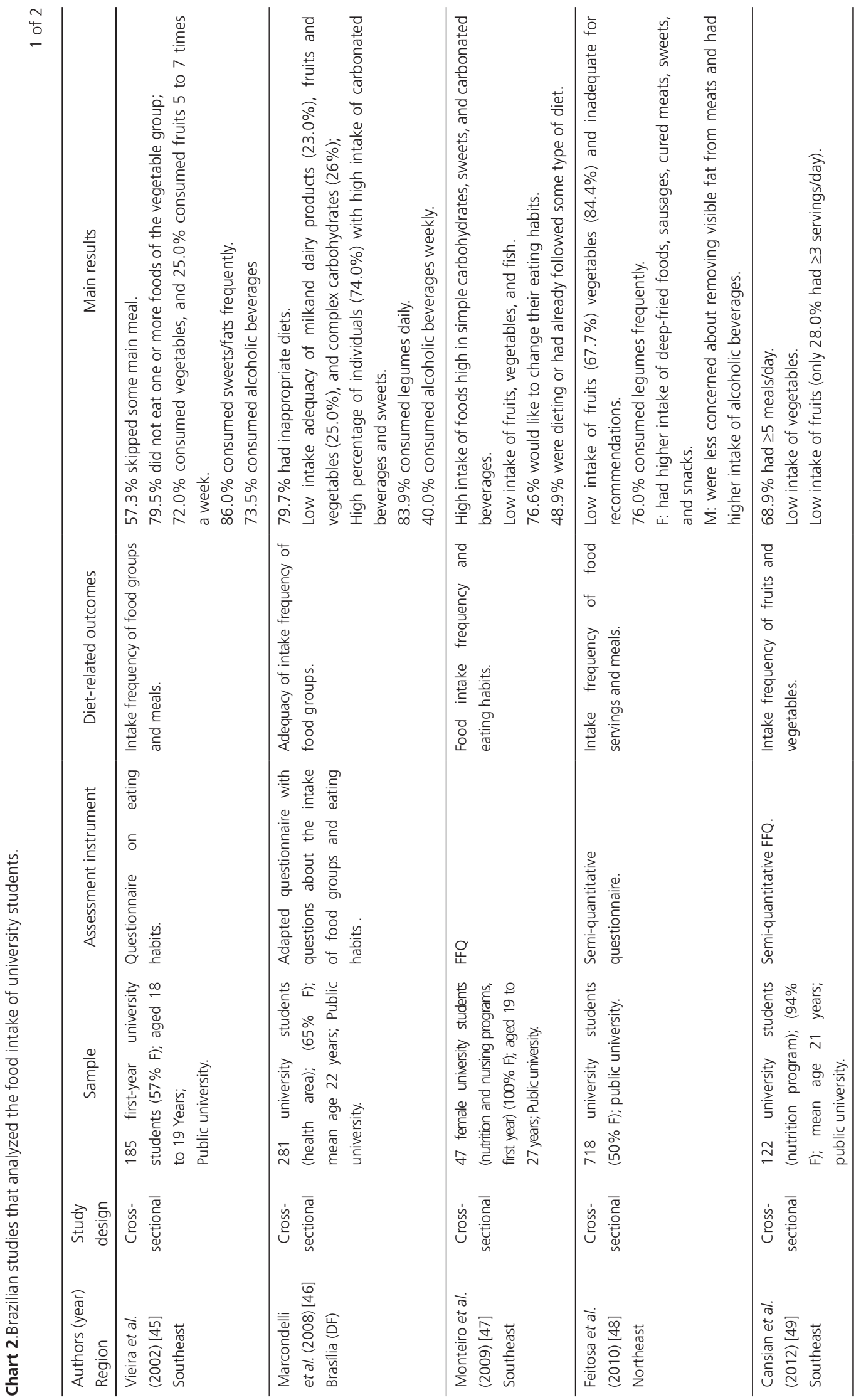




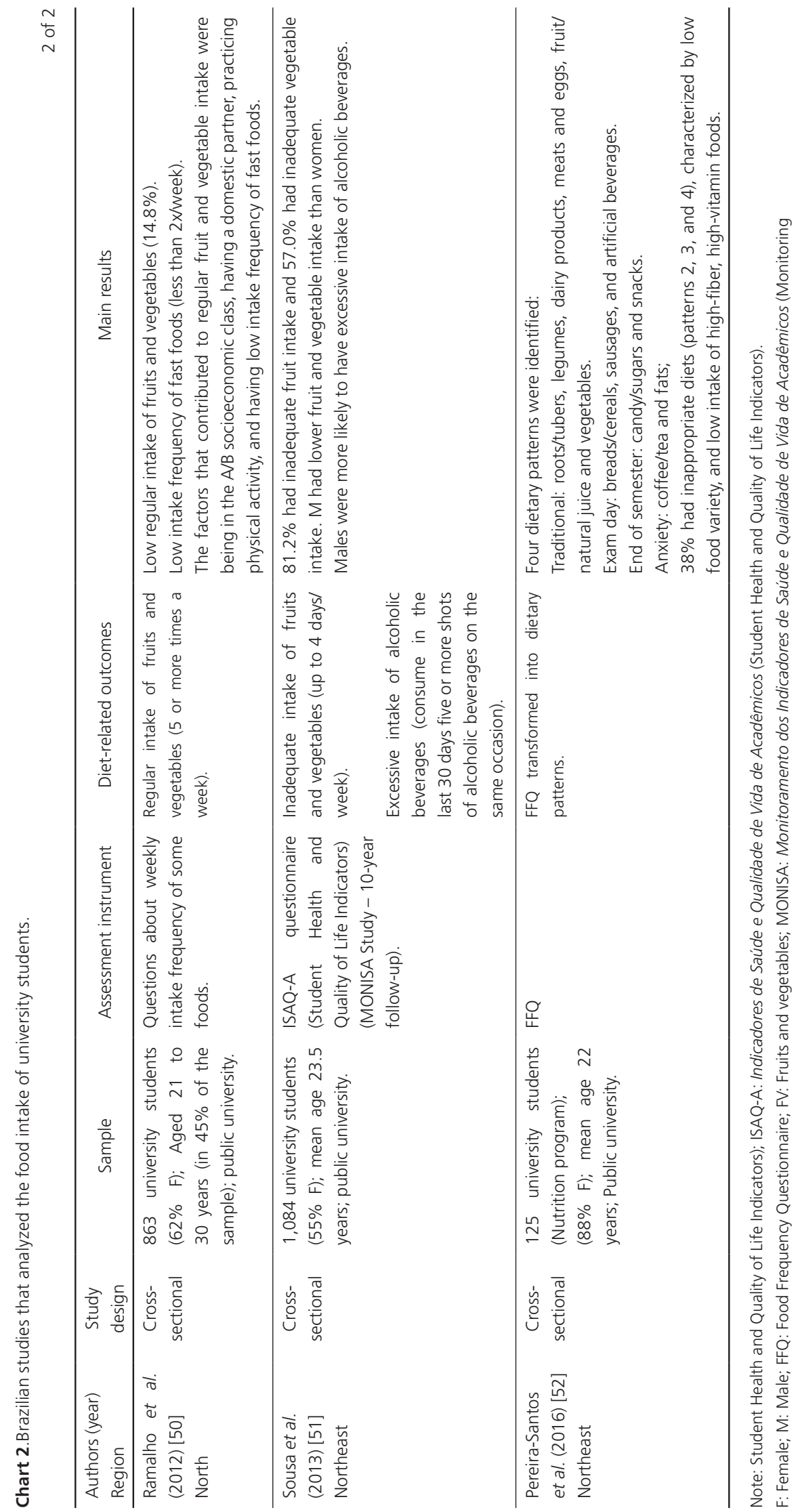


$[45,46,48,50]$. Given this context, the great methodological variety of the analyzed studies prevents comparing their results, which can be considered a limitation for extrapolating the results of this review. In addition, most studies used non-validated instruments.

Table 1 synthesizes the main characteristics found at the of the Brazilian and foreign studies results on the food intake of university students included in this review.

Foreign and Brazilian studies analyzed most characteristics of university students' food intake. Moreover, all studies, regardless of study site, made similar findings, such as the students' trend to consume unhealthy foods once they enter university.

\section{Relationship between food intake and variables related to the household, undergraduate program, and sex}

Many studies compared the food intake of university students who lived with their parents with the food intake of those who did not $[14-16,20,23,28,35,37]$. Students who lived with their parents did not change their eating habits considerably after entering university. In addition those who lived with their parents had more frequent intakes of fruits, vegetables, fish, meats, eggs, grains/breads, and legumes $[20,28,37]$.
On the other hand, students who moved out of their parents' homes changed their diets considerably, reducing their intake of foods prepared at home, fruits, vegetables, olive oil, nuts, seeds, and legumes, and increasing their intake of fast foods, ready-to-eat foods, sweets, carbonated beverages, and alcoholic beverages $[14-16,20,23,28,35,37]$. Hence, leaving the parents' home to attend university and having to assume responsibilities, such as food acquisition and preparation, may significantly affect the eating habits of university students.

The only longitudinal study on this subject found in the literature was conducted by Small et al. [23] in the United States; they followed 608 university students for seven academic semesters. Most students (98\%) lived on campus and had the negative tendency of reducing fruit and vegetables intake over time, but the positive tendency of reducing carbonated beverage intake over time.

Some studies compared the food intake of university students from health programs with those of students from non-health programs. Only two foreign studies, both conducted in Spain, found differences between those two groups, namely healthier eating habits [25] and higher adherence to the Mediterranean diet [32] in students from health programs. Nonetheless, most of results studies either emphasized inadequate intake of fruits, vegetables, fish,

Table 1. Main characteristics of the Brazilian and foreign study results on the food intake of university students.

\begin{tabular}{lcc}
\hline \multirow{2}{*}{ Results } & \multicolumn{2}{c}{ Article frequency $(\%)$} \\
\cline { 2 - 3 } Skipping breakfast $[13,29,34,36,38-41,45]$ & $\mathrm{F}(\mathrm{n}=29)$ & $\mathrm{B}(\mathrm{n}=8)$ \\
Having breakfast daily $[17,26,27,30]$ & 24.1 & 12.5 \\
Habitually snacking or skipping meals $[13,29,40,45]$ & 13.8 & - \\
Low intake of fruits and vegetables $[13,15,17,18,20,23,26,27,29,30-36,38-41,45-51]$ & 10.3 & 12.5 \\
Low intake of fish $[15,17,26,27,29,33,34,41,47]$ & 69.0 & 87.5 \\
High intake of carbonated beverages $[13,17,23,25,29,34,40,46,47]$ & 27.6 & 12.5 \\
High intake of alcoholic beverages $[15,28,34,45,46,48,51]$ & 24.1 & 25.0 \\
High intake of fast foods, snacks, and sweets $[15,18,20,33,34,36,39,41,46,47,50]$ & 10.3 & 50.0 \\
\hline
\end{tabular}

Note: F: Foreign; B: Brazilian. 
and whole grains, and high intake of fast foods by students enrolled in health programs $[25,32,34,39,41]$, or found no differences between those two groups [39]. Only Nola et al. [18] found that most of the 441 Croatian Medicine students in their sample consumed fruits and vegetables daily.

Some studies tried to analyze the differences in the food intake of male and female university students. Teleman et al. [38] observed that women consumed more fruits and vegetables than men. Yet, other studies found that both genders had low intake of fruits and vegetables $[17,40]$. Studies of females only also found low intake of fruits and vegetables by most, and the need to improve diet quality $[24,31,36,41]$.

In this sense, although sex may affect food intakes, this relationship in the reviewed studies is not clear. Some studies report that women have healthier eating habits than men [38,51], but others have found no differences between men and women $[17,40,48]$. Still, regardless of sex, university students' intake of fruits and vegetables remains low $[17,24,31,36,40,41,47,51]$.

Studies of Saudi Arabian [36] and Polish [41] conducted only with women shows that most of them (>80\%) had or preferred to have their meals at home. The habit of home cooking has been discussed in the literature, especially the relationship of the development of cooking skills with healthier eating habits, including weekly intake of fruits and vegetables and lower intake of processed foods and ready-to-eat foods [54]. Wolfson et al. [55] studied almost ten thousand adult Americans and found a significant association of the habit of making dinner/supper at home with better diet quality and lower intakes of fast foods, ready-to-eat meals, and frozen meals.

\section{Barriers to and facilitators of healthful eating in university students}

The outcomes of some studies analyzed were not only related to food intake but also to a wider context that involves barriers to and facilitators of the acquisition of healthier eating habits.

Al-Otaibi [31] found that the main barriers for the intake of fruits and vegetables by their sample of 960 female Saudi Arabian university students were: lack of time to prepare their own meal and the absence of fruits and vegetables in the university cafeteria. Another study conducted in Saudi Arabia by Majeed [36] corroborated these results as he found that the main barrier to a healthful diet was lack of time and lack of access to healthy foods.

The two studies above corroborate other studies that analyzed facilitators of and barriers to healthful eating in adolescents and young adults, namely: lack of time, financial instability, lack of cooking skills, cooking knowledge, space, and kitchen appliances, and easy access to unhealthy and convenience foods, including fast foods [7-10].

A population-based cohort study included American adolescents and young adults who cited some facilitators of fruit and vegetable intake, namely, personal preference for the taste of vegetables, less importance of the barrier of lack of time, higher availability of vegetables at home, homemade recipes based on vegetables, and the habit of consuming fruits for breakfast. Besides, the main limitation mentioned by the students was home availability of unhealthy foods. Thus, the authors emphasized that personal factors (food preferences) and socioenvironmental factors (home food availability) may influence the intake of fruits and vegetables in young adults, including university students [5].

Also in the United States, a qualitative study of 115 university students found that the main barriers and enablers for healthful weight management were: intrapersonal factors (craving for some food and lack of discipline); interpersonal factors (social situations); and environmental factors (lack of time and easy access to unhealthy foods or meals at the cafeteria, lack of access to healthy foods, and 
the higher cost associated with healthier eating habits). The cited facilitators were: intrapersonal factors (regular food intake and physical activity), interpersonal factors (social support), and environmental factors (university environment that facilitates the intake of healthy foods and physical activity). Yet, factors seen as barriers by some students, such as accessibility to the university cafeterias, were seen as facilitators by other students given how they perceived the availability of healthy foods at the universities [7].

A qualitative study of 35 Belgium university students identified the factors that influence behaviors that promote healthful eating, namely: personal (flavor preferences, self-discipline, autonomy, lack of time, and convenience); related to social networks (lack of parental and friend support); physical environment (healthy food availability and accessibility, attractiveness, and price); and macro-environment (media and advertising). The relationships between eating behavior determinants seem to be moderated by the university's environmental characteristics, such as residence halls, student societies, university lifestyle, and exams. Regarding lack of time, some students prefer to use their free time for activities other than food preparation, especially when they have to cook only for themselves. When they cook, they prefer meals that can be prepared more quickly so that they can spend more time watching television, and they also reported that they have more time for cooking after the exams [10].

The foods available at the university snack bars and cafeteria may also influence the food choices of students and other members of the university community. A study conducted at a public university in the Brazilian South used a census to analyze all campus food environment, including all restaurants $(n=6)$ and snack bars $(n=13)$ available to selling of foods and beverages. The foods sold by those places had low nutritional quality, and the healthiest foods were the most expensive. Therefore, both availability and higher prices of products not promote healthy food choices in the university environment [56].

Brazilian university restaurants are part of the students' food environment, especially at public universities as they are subsidized by the Programa Nacional de Assistência Estudantil (National Student Assistance Program), managed by the Ministry of Education, whose aim is to support low-income undergraduate students who attend federal higher-education institutions. Therefore, university restaurants should be encouraged to provide proper meals [11] because they have the potential to offer healthy foods, such as fruits, vegetables, and whole grains [56].

Some authors have suggested that the university campus may consist of a privileged scenario to incentivize health-promoting strategies, including interventions aimed at student autonomy $[1,11,53]$. In Brazil some reference documents provide health-promoting strategies, such as the Marco de Referência de Educação Alimentar e Nutricional (Food and Nutrition Education Landmark) [57] and the Dietary Guidelines for the Brazilian Population [58]. Still, nationwide public policies that promote healthful eating in the university community do not exist, hence the importance of developing strategies that, for example, encourage cooking skills through interventions or by making health foods more available and accessible at the university.

\section{FINAL CONSIDERATIONS}

This review synthesized the main results of studies on the food intake of university students and discussed the possible barriers to and facilitators of healthful eating. The results of said studies suggest that most university students had unhealthy food intakes, characterized by high intake of fast foods, snacks, sweets, and carbonated beverages, and low intake of fruits, 
vegetables, fish, whole grains, and legumes, and they habitually skipped main meals and had unhealthy snacks throughout the day. Moreover, university students who did not live with their parents had less healthy eating habits than those who did, after entered at university. Generally, the results of Brazilian and foreign studies made similar findings on the food intake of university students.

These results may help to create a picture of the food intake of university students and provide data for future actions that aim to promote healthful eating in this group.

Given the time these students spend at the university, the university environment is an interesting place for the development of public policies that aim to promote health and healthful eating in the university community. Public policies that promote healthful eating in students should be created, such as interventions to change dietary practices and increase access to healthy foods in the university environment.

\section{CONTRIBUTORS}

GL BERNARDO contributed to the planning and design of the manuscript; data collection, analysis, and interpretation data; drafting and critical revision of the manuscript; approved the final manuscript. MM JOMORI and AC FERNANDES contributed with analysis and interpretation data; critical revision of the manuscript; approved the final manuscript. RPC PROENÇA was responsible for the planning and design of the manuscript; analysis, and interpretation data; critical revision of the manuscript; approved the final manuscript.

\section{REFERE N CES}

1. Nelson MC, Story M, Larson NI, Neumark-Sztainer D, Lytle LA. Emerging adulthood and college aged youth: An overlooked age for weight-related behavior change. Obesity. 2008;16(10):2205-11. https://doi.org/10.1038/oby.2008.365

2. Larson $\mathrm{NI}$, Nelson MC, Neumark-Sztainer D, Story M, Hannan PJ. Making time for meals: Meal structure and associations with dietary intake in young adults. J Am Diet Assoc. 2009;109(1):72-9. https://doi.org/10.1016/j.jada.2008.10.017

3. Kapinos KA, Yakusheva O, Eisenberg D. Obesogenic environmental influences on young adults: Evidence from college dormitory assignments. Econ Hum Biol. 2014;12:98-109. https://doi. org/10.1016/j.ehb.2013.05.003

4. Huang $Y$, Song WO, Schemmel RA, Hoerr SM. What do college students eat? Food selection and meal pattern. Nutr Res. 1994;14(8):1143-53. https://doi.org/10.1016/S0271-5317(05)80242-8

5. Larson N, Laska MN, Story M, Neumark-Sztainer $D$. Predictors of fruit and vegetable intake in young adulthood. J Acad Nutr Diet. 2012;112(8):1216-22. https://doi.org/10.1016/j.jand.2012.03.035

6. Deliens T, Clarys P, Bourdeaudhuij I, Deforche B. Weight, socio-demographics, and health behaviour related correlates of academic performance in first year university students. Nutr J. 2013;12(162):1-9. https://doi.org/10.1186/1475-2891-12-162

7. Greaney ML, Less FD, White AA, Dayton SF, Riebe $D$, Blissmer $B$, et al. College students' barriers and enablers for healthful weight management: A qualitative study. J Nutr Educ Behav. 2009;41:2816. https://doi.org/10.1016/j.jneb.2008.04.354

8. Soliah LAL, Walter JM, Jones SA. Benefits and barriers to healthful eating: What are the consequences of decreased food preparation ability? Am J Lifestyle Med. 2012;6(2):152-8. https://doi.org/10.1177/1559827611426394

9. Graham DJ, Pelletier JE, Neumark-Sztainer D, Lust K, Laska MN. Perceived social-ecological factors associated with fruit and vegetable purchasing, preparation, and consumption among young adults. J Acad Nutr Diet. 2013;113(10):1366-74. https://doi.org/10.1016/j.jand.2013.06.348

10. Deliens T, Clarys P, Bourdeaudhuij I, Deforche B. Determinants of eating behaviour in university students: A qualitative study using focus group discussions. BMC Public Health. 2014;14(53):1-12. https://doi.org/10.1186/1471-2458-14-53.

11. Alves HJ, Boog MCF. Comportamento alimentar em moradia estudantil: um espaço para promoção da saúde. Rev Saúde Pública. 2007;41(2):197-204. https://doi.org/10.1590/S00 34-89102007000200005

12. Ministério da Saúde (Brasil). Departamento de Atenção Básica. Guia alimentar para a população brasileira: promovendo a alimentação saudável. Brasília: Ministério da Saúde; 2008 [acesso 2017 abr 19]. Disponível em: http://bvsms.saude.gov. br/bvs/publicacoes/guia_alimentar_populacao_ brasileira_2008.pdf 
13. Huang Y, Song WO, Schemmel RA, Hoerr SM. What do college students eat? Food selection and meal pattern. Nutr Res. 1994;14(8):1143-53. https://doi.org/10.1016/S0271-5317(05)80242-8

14. Papadaki A, Hondros G, Scotta JA, Kapsokefalou M. Eating habits of University students living at, or away from home in Greece. Appetite. 2007;49(1):169-76. https://doi.org/10.1016/j.appet. 2007.01.008

15. Kremmyda LS, Papadaki A, Hondros G, Kapsokefalou M, Scott JA. Differentiating between the effect of rapid dietary acculturation and the effect of living away from home for the first time, on the diets of Greek students studying in Glasgow. Appetite. 2008;50(2-3):455-63. https://doi.org/10.1016/j.appet.2007.09.014

16. Laska MN, Larson NI, Neumark-Sztainer D, Story M. Dietary patterns and home food availability during emerging adulthood: Do they differ by living situation? Public Health Nutr. 2009;13(2):222-8. https://doi.org/10.1017/S1368980009990760

17. Pérusse-Lachance E, Tremblay A, Drapeau V. Lifestyle factors and other health measures in a Canadian university community. Appl Physiol Nutr Metab. 2010;35(4):498-506. https://doi.org/10. 1139/H10-035

18. Nola IA, Jelinié JD, Matanié $D$, Pucarin-Cvetkovié J, Markovié BB, Senta A. Differences in eating and lifestyle habits between first- and sixth-year medical students from Zagreb. Coll Antropol. 2010;34(4):1289-94.

19. Cefai C, Camilleri L. The dietary habits of Maltese university students. Malta Med J. 2011;23(2):7-12.

20. Ansari WE, Stock C, Mikolajczyk R. Relationships between food consumption and living arrangements among university students in four European countries: A cross-sectional study. Nutr J. 2012;11(28):1-7. https://doi.org/10.1186/1475-2 891-11-28

21. Ortiz-Moncada R, Navarro AIN, Marti AZ, Sáez JF, Blanes MCD. ¿Siguen patrones de dieta mediterránea los universitarios españoles? Nutr Hosp. 2012;27(6):1952-9. https://doi.org/10.33 05/nh.2012.27.6.6091

22. Moreno-Gómez C, Romaguera-Bosch D, TaulerRiera $P$, Bennasar-Veny $M$, Pericas-Beltran J, Martinez-Andreu $S$, et al. Clustering of lifestyle factors in Spanish university students: The relationship between smoking, alcohol consumption, physical activity and diet quality. Public Health Nutr. 2012;15(11):2131-9. https:// doi.org/10.1017/S1368980012000080

23. Small M, Bailey-Davis L, Morgan N, Maggs J. Changes in eating and physical activity behaviors across seven semesters of college: Living on or off campus matters. Health Edu Behav. 2012;40(4):435-41. https://doi.org/10.1177/10 90198112467801

24. Strawson C, Bell R, Downs S, Farmer A, Olstad $D$, Willows $N$. Dietary Patterns of female university students with nutrition education. Can J Diet Pract Res. 2013;74(3):138-42. https://doi. org/10.3148/74.3.2013.138

25. Zazpe I, Marqués M, Sánchez-Tainta A, RodríguezMourille A, Beunza J, Santiago S. Hábitos alimentarios y actitudes hacia el cambio en alumnos y trabajadores universitarios españoles. Nutr Hosp. 2013;28(5):1673-80. https://doi. org/10.3305/nh.2013.28.5.6553

26. Burriel FC, Urrea RS, García CV, Tobarra MM, Meseguer MJG. Hábitos alimentarios y evaluación nutricional en una población universitária. Nutr Hosp. 2013;28(2):438-46. https://doi.org/10.33 05/nh.2013.28.2.6303

27. Travé TD. Análisis nutricional del desayuno y almuerzo en una población Universitaria. Nutr Hosp. 2013;28(3):1291-9. https://doi.org/10.330 5/nh.2013.28.4.6597

28. Bagordo F, Grassi T, Serio F, Idolo A, De Donno A. Dietary habits and health among university students living at or away from home in Southern Italy. J Food Nutr Res. 2013;52(3):164-71.

29. Likus W, Milka D, Bajor G, Jachacz-Łopata M, Dorzak B. Dietary habits and physical activity in students from the medical University of Silesia in Poland. Rocz Panstw Zakl Hig. 2013;64(4):317-24.

30. García-Meseguer MJ, Burriel FC, García CV, Serrano-Urrea R. Adherence to Mediterranean diet in a Spanish university population. Appetite. 2014;78(1):156-64. https://doi.org/10.1016/j.appet. 2014.03.020

31. AL-Otaibi $\mathrm{HH}$. The pattern of fruit and vegetable consumption among Saudi university students. Global J Health Science. 2014;6(2):155-62. https:// doi.org/10.5539/gjhs.v6n2p155

32. Pérez-Gallardo L, Gómez TM, Marzo IB, Pascual MAF, Calle EM, Domínguez RR, et al. Calidad de la dieta en estudiantes universitários con distinto perfil académico. Nutr Hosp. 2015;31(5):2230-9. https://doi.org/10.3305/nh.2015.31.5.8614

33. De Piero A, BassettN, Rossi A, Sammán N. Tendencia en el consumo de alimentos de estudiantes universitários. Nutr Hosp. 2015;31(4):1824-31. https://doi.org/10.3305/nh.2015.31.4.8361

34. Agüero SD, Godoy EF, Fuentes JF, Fernández $\mathrm{AH}$, Muñoz CQ, Hidalgo WY, et al. Patrones alimentarios asociados a un peso corporal saludable em estudiantes chilenos de la carrera de 
nutrición y dietética. Nutr Hosp. 2015;32(4):1780-5. https://doi.org/10.3305/nh.2015.32.4.9515

35. Alsunni AA, Badar A. Fruit and vegetable consumption and its determinants among Saudi university students. J Taibah Univ Med Sci. 2015;10(2):201-7. https://doi.org/10.1016/j. jtumed.2014.11.003

36. Majeed F. Association of BMI with diet and physical activity of female medical students at the University of Dammam, Kingdom of Saudi Arabia. J Taibah Univ Med Sci. 2015;10(2):188-96. https:// doi.org/10.1016/j.jtumed.2014.11.004

37. Lupi S, Bagordo F, Stefanati A, Grassi T, Piccinni $L$, Bergamini $M$, et al. Assessment of lifestyle and eating habits among undergraduate students in northern Italy. Ann Ist Super Sanità. 2015;51(2):154-61. https://doi.org/10.4415/ANN_ 15_02_14

38. Teleman AA, Waure C, Soffiani V, Poscia A, Di Pietro ML. Nutritional habits in Italian university students. Ann Ist Super Sanità. 2015;51(2):99-105. https://doi.org/10.4415/ANN_15_02_05

39. Gresse A, Steenkamp L, Pietersen J. Eating, drinking and physical activity in Faculty of Health Science students compared to other students at a South African university. S Afr J Clin Nutr. 2015;28(4):154-9. https://doi.org/10.1080/1607 0658.2015.11734555

40. Mahfouz MS, Makeen AM, Akour AY, Madkhly TM, Hakami HM, Shaabi WM, et al. Nutritional habits and weight status among Jazan university students: Eating patterns and healthy lifestyle assessment. Epidemiol Biostat Public Health. 2016;13(2):e11658. https://doi. org/10.2427/11658

41. Kowalcze K, Turyk Z, Drywień M. Nutrition of students from dietetics profile education in the Siedlce University of natural sciences and humanities compared with students from other academic centres. Rocz Panstw Zakl Hig. 2016;67(1):51-8.

42. Hoyland A, Dye L, Lawton CL. A systematic review of the effect of breakfast on the cognitive performance of children and adolescents. Nutr Res Rev. 2009;22(2):220-43. https://doi.org/10.1017/ S0954422409990175

43. Timlin MT, Pereira MA, Story M, NeumarkSztainer D. Breakfast eating and weight change in a 5-year prospective analysis of adolescents: Project EAT (Eating Among Teens). Pediatrics. 2008;121(3):E638-45. https://doi.org/10.1542/ peds.2007-1035

44. Barr SI, Di Francesco L, Fulgoni VL. Breakfast consumption is positively associated with nutrient adequacy in Canadian children and adolescents. Br J Nutr. 2014;112(8):1373-83. https://doi.org/10. 1017/S0007114514002190

45. Vieira VCR, Priore SE, Ribeiro SMR, Franceschini SCC, Almeida LP. Perfil socioeconômico, nutricional e de saúde de adolescentes recém-ingressos em uma universidade pública brasileira. Rev Nutr. 2002;15(3):273-82. https://doi.org/10.1590/S14 15-52732002000300003

46. Marcondelli P, Costa THM, Schmitz BAS. Nível de atividade física e hábitos alimentares de universitários do $3^{\circ}$ ao $5^{\circ}$ semestres da área da saúde. Rev Nutr. 2008;21(1):39-47. https://doi. org/10.1590/S1415-52732008000100005

47. Monteiro MRP, Andrade MLO, Zanirati VF, Silva RR. Hábito e consumo alimentar de estudantes do sexo feminino dos cursos de Nutrição e de Enfermagem de uma universidade pública brasileira. Rev Atenção Primária Saúde. 2009;12(3):271-7.

48. Feitosa EPS, Dantas CAO, Andrade-Wartha ERS, Marcellini PM, Mendes-Netto RS. Hábitos alimentares de estudantes de uma universidade pública. Aliment Nutr. 2010;21(2):225-30.

49. Cansian ACC, Gollino L, Alves JBO, Pereira EMS. Avaliação da ingestão de frutas e hortaliças entre estudantes universitários. Nutrire. 2012;37(1):5463. https://doi.org/10.4322/nutrire.2012.005

50. Ramalho AA, Dalamaria T, Souza OF. Consumo regular de frutas e hortaliças por estudantes universitários em Rio Branco, Acre, Brasil: prevalência e fatores associados. Cad Saúde Pública. 2012;28(7):1405-13. https://doi.org/10.1590/S010 2-311X2012000700018

51. Sousa TF, José HPM, Barbosa AR. Condutas negativas à saúde em estudantes universitários brasileiros. Ciênc Saúde Coletiva. 2013;18(12):3563-75. http://dx.doi.org/10.1590/ S1413-81232013001200013

52. Pereira-Santos M, Santana JM, Carvalho ACN, Freitas F. Dietary patterns among nutrition students at a public university in Brazil. Rev Chil Nutr. 2016;43(1):39-44. https://doi.org/10.4067/ S0717-75182016000100006

53. Maciel ES, Sonati JG, Modeneze DM, Vasconcelos JS, Vilarta R. Consumo alimentar, estado nutricional e nível de atividade física em comunidade universitária brasileira. Rev Nutr. 2012;25(6):707-18. https://doi.org/10.1590/S141 5-52732012000600003

54. Reicks M, Trofholz AC, Stang JS, Laska MN. Impact of cooking and home food preparation interventions among adults: Outcomes and implications for future programs. J Nutr Educ Behav. 2014;46(4):259-76. https://doi.org/10.10 16/j.jneb.2014.02.001 
55. Wolfson JA, Bleich SN. Iscooking athomeassociated with better diet quality or weight-loss intention? Public Health Nutr. 2014;18(8):1397-406. https:// doi.org/doi:10.1017/\$1368980014001943

56. Pulz IS, Martins PA, Feldman C, Veiros MB. Are campus food environments healthy? A novel perspective for qualitatively evaluating the nutritional quality of food sold at foodservice facilities at a Brazilian university. Perspect Public Health. 2017;137(2):122-35. https://doi.org/10. 1177/1757913916636414

57. Ministério do Desenvolvimento Social e Combate à Fome (Brasil). Marco de referência de educação alimentar e nutricional para as políticas públicas. Brasília: Ministério do Desenvolvimento Social e Combate à Fome; 2012 [acesso 2016 jul 18].
Disponível em: http://www.mds.gov.br/web arquivos/publicacao/seguranca_alimentar/marco_ EAN.pdf

58. Ministério da Saúde (Brasil). Departamento de Atenção Básica. Guia alimentar para a população brasileira: promovendo a alimentação saudável. $2^{a}$ ed. Brasília: Ministério da Saúde; 2014 [acesso 2016 jul 18]. Disponível em: http://portalsaude. saude.gov.br/images/pdf/2014/novembro/05/ GuiaAlimentar-para-a-pop-brasiliera-MioloPDFInternet.pdf

Received: September 12, 2016 Final version: May 2, 2017 Approved: May 24, 2017 